\title{
A preliminary study on the potential use of an alternative bait for demersal longline fishery; Sepietta sp.
}

\section{Paragat avcılığında alternatif bir yem kullanımı üzerine ön çalışma; Sepietta sp.}

\author{
Ozan Soykan* • İlker Aydın • Hasan Tuncay Kınacıgil \\ Ege University, Fisheries Faculty, 35100 Bornova, Izmir - Turkey \\ *Corresponding author: ozansoykan@hotmail.com
}

How to cite this paper:

Soykan, O., Aydın, I. \& Kınacıgil, H. T. (2016). A preliminary study on the potential use of an alternative bait for demersal longline fishery; Sepietta sp. Ege Journal of Fisheries and Aquatic Sciences, 33(2): 163-.167 doi: 10.12714/egejfas.2016.33.2.11

\begin{abstract}
This study was carried out between September 2007 and April 2008 in the Aegean Sea with an experimental longline. Traditional baits such as Sardina pilchardus and Solen vagina were used with Sepietta sp. which is a discarded species from Aegean Sea demersal trawl fishery. 438 individuals belonging to 6 families were obtained and they totally weighed $43.1 \mathrm{~kg}$. It was determined that almost half of the specimens were captured by Sepietta sp. Furthermore individuals caught by this alternative bait composed $45 \%$ of the total catch in terms of weight. Results showed that Sepietta sp. was the most efficient bait among all baits used in the study. The use of this species as a bait in longline fishery has also another importance from the perspective of evaluating a trawl discarded species.
\end{abstract}

Keywords: Longline, bait, Sepietta sp., small scale fishery.

Öz: Bu çalışma Eylül 2007-Nisan 2008 tarihleri arasında deneysel amaçlı hazırlanmış bir paragat takımıyla Ege Denizi'nde gerçekleştrilmiştir. Geleneksel yemler olan Sardina pilchardus ve Solen vagina, Ege Denizi demersal trol avcilığında ıskarta edilen bir yem olan Sepietta sp. ile birlikte kullanılmıștı. Altı familyaya ait toplam 438 birey yakalanmış ve toplam ağırlıkları $43,1 \mathrm{~kg}$ olarak bulunmuştur. Yakalanan bireylerin yarısına yakın kısmı Sepietta sp. ile yakalanmıştı. Bununla beraber bu alternatif yem ile yakalanan bireyler toplam avın ağırlık olarak \% 45 'ini oluşturmuşlardır. Sonuçlar Sepietta sp.'nin tüm yemler içinde en etkili yem olduğunu göstermiştir. Bu türün paragat balıkçıı̆ında yem olarak kullanımının, trol avcılı̆ıından ıskarta edilen bir türün değerlendirilmesi açııından ayrı bir önemi bulunmaktadır.

Anahtar kelimeler: Paragat, yem, Sepietta sp., küçük ölçekli balıkçılık

\section{INTRODUCTION}

Longline, as being one of the passive fishing gears has been traditionally used all around the world (Lokkeborg and Bjordal, 1992). Longline fishing is classified in small scale fishery as a commercial fishing technique. It uses a long line, called the main line, with many baited or unbaited hooks attached at intervals by means of branch lines called snoods (or gangions) (Bjordal, 2002). Longlines can be set near the surface (pelagic longline) to catch pelagic fish such as tuna and swordfish or along the sea floor (demersal longline) for groundfish such as sea breams, halibut or cod. Catching efficiency of longlines may be affected by several technical, biological and environmental factors such as the mainline and snood material, the hook design and size, rigging, and the type and size of the bait (Løkkeborg and Pina, 1997). There are many factors that influence selectivity and catch in longline fishery and the most important are bait and hook (Jacobsen and
Joensen, 2004).

Longline fishery is very common in the Aegean and Mediterranean coasts of Turkish Seas. Fishery is mostly conducted daily by small vessels (6-10 m length) with one or two fishermen. Longliners commonly use traditional baits such as European pilchard (Sardina pilchardus), European anchovy (Engraulis encrasicolus), common cuttlefish (Sepia officinalis), tubular sea cucumber (Holothuria tubulosa) and banded dyemurex (Hexaplex trunculus). Furthermore, gilthead seabream (Sparus aurata), common dentex (Dentex dentex), pink dentex (Dentex gibbosus), common pandora (Pagellus erythtinus), white seabream (Diplodus sargus sargus), common twobanded sea bream (Diplodus vulgaris), groupers (Epinephelus spp.) and swordfish (Xiphias gladius) are the main target species of demersal and pelagic longline fishery in Turkey. 
Genus Sepietta is a member of family Sepiolidae. It includes 5 species; Rondeletiola minor, Sepietta neglecta, Sepietta obscura, Sepietta oweniana, Sepietta petersi (Sealifebase, 2016) and they are commonly named as bobtail squid. All mentioned species except $S$. obscura are all in the red list of IUCN with DD (data deficiency) status. These species are a part of by-catch in trawl fishery and have been marketed locally for human consumption in the Mediterranean region (FAO, 2005). Furthermore Sepietta species have been discarded due to its small size in the Aegean Sea demersal trawl fishery (Soykan, 2011).

In this study, it was aimed to determine the potential use of Sepietta sp. as an alternative bait for demersal longline fishery.

\section{MATERIAL AND METHODS}

İzmir Bay (Urla), Dalyanköy (Çeşme) and Karaburun were the study area (Figure 1) as being one of the region's most important fishing grounds for demersal longlining. A total of 30 experimental fishing sets ( 2970 hooks) were performed during September 2007-April 2008 with a 6 m length traditional type boat. Furthermore depths of the sets ranged between 4-17 meters. Longline was prepared with traditional 14 no $\mathrm{J}$ hook model (Mustad 1250D) which is commonly used by fishermen in the Aegean Sea. Experimental longline included 99 hooks in order to create the same probability of capture for each bait (each bait was used on 33 hooks per operation). Baits were $S$. pilchardus, S. vagina and Sepietta sp., and they alternated along the main line with the same order. Bait pieces were standardised to $3 \mathrm{~cm}$ long which is the average mantle length of Sepietta sp. individuals in order to avoid the effect of bait size on fish length. Point, barb and bend of the hooks were totally covered with baits. Mainline and the branchlines were made of nylon monofilament. Diameter of the mainline was 0.45 and the snood was $0.30 \mathrm{~mm}$ with a snood length of $100 \mathrm{~cm}$. The distance between two snoods was $500 \mathrm{~cm}$. Gear was deployed during afternoon and drifted during sundown. Duration of the operations were standardised to 3 hours. We recorded the species and the bait type at the time of haulback. Afterwards, fish samples were brought to the laboratory and total length $(\mathrm{TL})$ was measured in the natural body position to the nearest $\mathrm{mm}$. Total weight $(\mathrm{W})$ was measured to the nearest $0.1 \mathrm{~g}$. Catch per unit effort (CPUE) and Yield per unit effort (YPUE) calculations were based on the total catch per each bait. CPUE and YPUE were calculated according to Godøy et al., 2003;

$$
\begin{aligned}
& \text { CPUE }=\frac{\sum n}{\sum h^{*} \sum t} * 100 \\
& Y P U E=\frac{\sum w}{\sum h^{*} \sum t} * 100
\end{aligned}
$$

$\mathrm{n}$; number of individuals

w; weight of individuals

$\mathrm{h}$; number of hooks

$\mathrm{t}$; number of operations
Only Diplodus annularis and Serranus scriba were analysed statiscally due to insufficient data for the rest of the species. Because of non-normal distribution and nonhomogeneity of variances (Levene test), statistical difference between the bait type and the length for individuals of $D$. annularis and S. scriba was tested by Kruskal-Wallis ANOVA. Data were evaluated by MS Excel 2007 and Statistica 12.0 software.

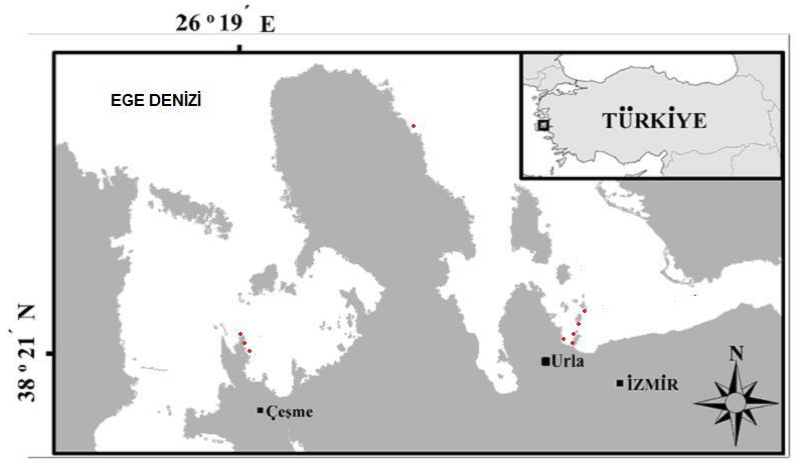

Figure 1. Study area of the longline trials; red points indicate the sampling stations

\section{RESULTS}

As a result of 2970 hook samplings (30 experimental longline deployments), 10 species belonging to 3 classis and 6 families were obtained. 438 individuals totally weighed $43.1 \mathrm{~kg}$ and captured species of the study were given in the Table 1. $D$. annularis and $S$. scriba were dominant in terms of number. It was found that $45 \%$ of the catch was captured with Sepietta sp. in terms of weight (Figure 2). 213 fish were hooked with Sepietta sp., 147 by S. vagina and 78 with S. pilchardus. CPUE values were calculated as $0.21 \mathrm{fish} / 100$ hooks, $0.08 \mathrm{fish} / 100$ hooks and 0.15 fish/100 hooks for Sepietta sp., S. pilchardus and $S$. vagina respectively. It was determined that Sepietta $s p$ had the highest YPUE value (19.8 gr/hooks) followed by $S$. pilchardus (13.8 gr/100 hooks) and S.vagina (10 gr/100 hooks). As the target species of the demersal longline fishery in the Aegean Sea are mostly the members of family Sparidae, Sepietta sp. captured more than $50 \% \quad(n=117)$ of the total number of sparids in comparison to the other baits. No significant statistical difference was found between the bait type and the length for individuals of $D$. annularis and $S$. scriba (Kruskal-Wallis ANOVA, $p>0.05$ ). The length range of $D$. annularis was from $11.8 \mathrm{~cm}$ to $18.8 \mathrm{~cm}$ for Sepietta sp., 12.1 $\mathrm{cm}$ to $16 \mathrm{~cm}$ for $S$. pilchardus and $11.5 \mathrm{~cm}$ to $18.6 \mathrm{~cm}$ for $S$. vagina. Another commercially important sparid, $S$. aurata, was not represented with enough number of individuals for statistical analyse, but the mean length and the mean weight of specimen captured with $S$. pilchardus are dramatically greater than that of Sepietta sp. (Table 1). On the other hand Sepietta $s p$. captured the individuals of $S$. aurata two times more than $S$. pilchardus did. It was found that the lengths of $S$. aurata captured with Sepietta sp. and S. pilchardus ranged from $18 \mathrm{~cm}$ to $32.4 \mathrm{~cm}$ and $32 \mathrm{~cm}$ to $36 \mathrm{~cm}$, respectively. 
Table 1. Descriptive statistics of captured specimen according to the bait type (SE; standart error)

\begin{tabular}{|c|c|c|c|c|c|c|c|c|c|c|c|c|c|c|c|}
\hline & \multicolumn{4}{|c|}{ Sepietta sp. } & \multicolumn{4}{|c|}{ Sardina pilchardus } & \multicolumn{4}{|c|}{ Solen vagina } & \multicolumn{3}{|c|}{ Total } \\
\hline & $\mathrm{n}$ & W & $\begin{array}{l}\text { Lmean } \\
\pm S E\end{array}$ & $\begin{array}{c}\text { Wmean } \\
\pm \text { s.e. }\end{array}$ & $n$ & W & $\begin{array}{l}\text { Lmean } \\
\pm \text { s.e. }\end{array}$ & $\begin{array}{c}\text { Wmean } \\
\pm \text { s.e. }\end{array}$ & $\mathrm{n}$ & W & $\begin{array}{l}\text { Lmean } \\
\pm \text { s.e. }\end{array}$ & $\begin{array}{c}\text { Wmean } \\
\pm \text { s.e. }\end{array}$ & $n$ & W & W\% \\
\hline \multicolumn{16}{|l|}{ MORONIDAE } \\
\hline Dicentrarchus labrax & & & & & 3 & 2147.5 & $41.0 \pm 2.7$ & $715.8 \pm 146.2$ & & & & & 3 & 2147.5 & 5.0 \\
\hline \multicolumn{16}{|l|}{ RAJIDAE } \\
\hline Raja sp. & & & & & 3 & 936.5 & $35.6 \pm 2.9$ & $312.2 \pm 36.4$ & & & & & 3 & 936.5 & 2.2 \\
\hline \multicolumn{16}{|l|}{ SCORPAENIDAE } \\
\hline Scorpaena sp. & & & & & 3 & 554.2 & $20.3 \pm 1.0$ & $184.7 \pm 11.3$ & & & & & 3 & 554.2 & 1.3 \\
\hline \multicolumn{16}{|l|}{ SERRANIDAE } \\
\hline Serranus scriba & 60 & 3891 & $16 \pm 0.3$ & $64.9 \pm 4.9$ & 12 & 1191.5 & $17.5 \pm 0.7$ & $99.3 \pm 9.3$ & 72 & 4098.4 & $15.7 \pm 0.2$ & $56.9 \pm 2.0$ & 144 & 9180.9 & 21.3 \\
\hline Serranus cabrilla & 3 & 307 & $19.4 \pm 0.3$ & $102.3 \pm 4.0$ & & & & & 9 & 780 & $16.5 \pm 0.7$ & $86.6 \pm 5.5$ & 12 & 1087 & 2.5 \\
\hline \multicolumn{16}{|l|}{ SPARIDAE } \\
\hline Diplodus annularis & 84 & 4000.2 & $14.0 \pm 0.2$ & $47.6 \pm 2.3$ & 24 & 1062 & $13.8 \pm 0.3$ & $44.3 \pm 3.3$ & 36 & 1594.5 & $13.8 \pm 0.3$ & $44.3 \pm 3.8$ & 144 & 6656.7 & 15.4 \\
\hline Sparus pagrus & 12 & 3624.1 & $21.9 \pm 0.8$ & $302 \pm 31.8$ & 3 & 447.3 & $17.1 \pm 1.2$ & $149.1 \pm 30.5$ & 3 & 160.7 & $10.9 \pm 0.9$ & $53.6 \pm 12.3$ & 18 & 4232.1 & 9.8 \\
\hline Sparus aurata & 18 & 2950 & $22.9 \pm 0.9$ & $163.9 \pm 23.2$ & 9 & 4197 & $34.2 \pm 0.5$ & $466.3 \pm 19.4$ & & & & & 27 & 7147 & 16.6 \\
\hline Pagellus erythrinus & 3 & 515.2 & $20.4 \pm 0.4$ & $171.7 \pm 4.7$ & & & & & & & & & 3 & 515.2 & 1.2 \\
\hline \multicolumn{16}{|l|}{ TRACHINIDAE } \\
\hline Trachinus draco & 33 & 4288.6 & $21.2 \pm 0.5$ & $129.9 \pm 6.8$ & 21 & 3097.5 & $22.5 \pm 0.2$ & $147.5 \pm 3.9$ & 27 & 3301.4 & $20.6 \pm 0.5$ & $122.3 \pm 5.4$ & 81 & 10687.5 & 24.8 \\
\hline TOTAL & 213 & 19576.1 & & & 78 & 13633.5 & & & 147 & 9935 & & & 438 & 43144.6 & 100 \\
\hline
\end{tabular}

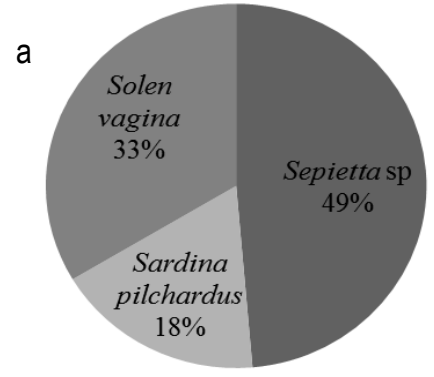

b

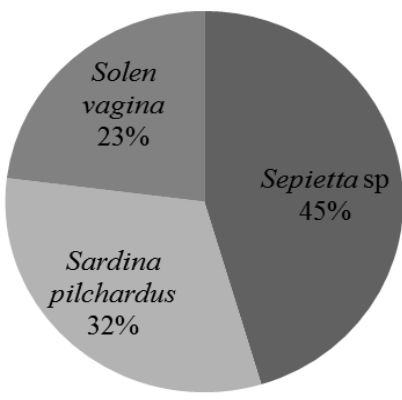

Figure 2. Distribution of the total catch according to the bait type in terms of number (a) and weight (b)

\section{DISCUSSION}

The longline is considered to be an environment-friendly fishing gear (Løkkeborg, 2000). It is considered to be species and size-selective, catching few non-target species, while the proportion of large fish of the target species is high (Løkkeborg \& Bjordal, 1992). It has less impact on natural habitats, discards of undersized and unwanted fish tend to be low and captured fish is high quality (Løkkeborg, 2000). On the contrary, longline fishing may cause the incidental mortality of sharks, echinoderms and some other species, many of which are either protected or endangered. Furthermore, there is no evidence of ghost fishing by lost lines, which in the case of gill net is a serious ecological problem (Hameed and Boopendranath, 2000). Therefore, it is very important to promote longline fishery to establish ecosystem based fishery management.
Important selection factors in the longline fishery were reported to be the fish distribution, fishing strategy, feeding range, fish competition, type and size of bait, and hook design (Lokeborg and Bjordal, 1992). Nevertheless the most important factors that influence the catch are the bait and the hook (Jacobsen and Joensen, 2004). If a fish is to consider a bait as food and eat it, then the bait must be more tempting than the available food in the area (Jacobsen and Joensen, 2004). If two kind of baits are used on the longline, then it could have a synergistic effect (Løkkeborg, 1989), meaning the two baits catch more fish than they would have on their own. There are several factors which influence the quality of bait such as smell, taste, texture and toughness/tenacity (Jacobsen and Joensen, 2004). For any bait, or combination of baits, to be successful in catching fish, it is reasonable to assume that it must stimulate both olfactory and gustatory responses (Jacobsen and Joensen, 2004). In addition the bait must have a certain 
physical strength, to ensure that it is not lost during setting, and that the bait is not torn off the hook while the fish biting (Jacobsen and Joensen, 2004). Lokkeborg and Pina (1997) reported that the catch efficiency is high when the bait is fresh and operations more than two hours reduces the catch efficiency. The baits used in our study have different features. S. pilchardus have a powerful smell to attract fish around, but it is very weak and vulnerable against even little biting attempts. On the other hand $S$. vagina and Sepietta sp. are more visible and visually attractive than $S$. pilchardus but they have less potential to cover olfactory responses of fish. Furthermore $S$. pilchardus and $S$. vagina are frequently used in the recreational fishery of the Aegean Sea. Almost half of the fish were captured with Sepietta $s p$ in the present work. The success of Sepietta $s p$ is considered to be due to its resistant structure and visibility. Özdemir et al. (2006) compared two baits; sardine and squid, determined that squid as being more resistant and brighter, was more efficient with a 78\% catch rate. Çekiç and Başusta (2004) reported that the bait sardine caught more fish than that of cuttle fish in İskenderun Bay. The differences between the results of the studies are attributable to regional and operational factors such as hook type and timing. Bait type should also be considered not only for attractiveness or catchability but also for bait loss. He (1996) reported that the rate of bait loss was related to fishing ground depth, bait type and mainline type.

Regarding the catch composition, our results are similar with that of Ulaş and Düzbastılar (2001), both studies having 10 species mostly composed by sparids in the central Aegean Sea. In our study, $43 \%$ of the total number of individuals belonged to family Sparidae. Statistical analyse revealed no significant difference between the length and bait type for $D$. annularis and S. scriba which were the only two species including sufficient number of individuals for statistical evaluation. It is generally hard to get numerous numbers of individuals from the same species in multispecies longline fishery in comparison to trawl and purse seine. The mean length of the most important commercially sparid, $S$. aurata was found to be over the minimum landing size for $S$. pilchardus $(34.2 \mathrm{~cm})$ and Sepietta sp. $(22.9 \mathrm{~cm})$ which is reported as 20 cm TL for Turkey (Anonymus, 2012). Kınacıgil et al. (2008) reported the first gonad formation of $S$. aurata at 18.5 and 17.8 $\mathrm{cm}$ TL for males and females respectively. Mean lengths of our study for both baits were found to be over the first gonad

\section{REFERENCES}

Anonymous, (2012). Fisheries regulation for marine and fresh waters for commercial fishery, 2012-2016 fishing period No: 3/1 (in Turkish). Ministry of Agriculture and Rural Affair of Turkey, Protect and Control General Office, Ankara, p. 85

Bjordal, A. (2002). The use of technical measures in responsible fisheries: regulation of fishing gear. In: A fishery manager's guidebook-management measures and their application, Cochrane, K.L.(ed), FAO Fisheries Technical Paper 424, Rome, 21-48.

Çekiç, M. \& Başusta, N. (2004). Effect on the species selectivity of different bait and hook size in longline in Iskenderun Bay, eastern Mediterranean Sea (in Turkish with English abstract). Ege Journal of Fisheries and Aquatic Sciences, 21(1-2): 73-77. formation indicating a sustainable fishing for the species. Even though no statistical analyse could be applied on S. aurata, the length range between two baits for Sepietta sp. (18 to $32.4 \mathrm{~cm}$ ) and $S$. pilchardus $(32$ to $36 \mathrm{~cm}$ ) seemed different. From this point of view, it can be said that relatively smaller individuals prefer Sepietta $s p$. compared to S. pilchardus. On the other hand minimum lending size for many species in the longline fishery catch composition has still not been reported by the legislative authority. This parameter must be determined for the other species in order to enable for an ecosystem based fishery management. Although there are 3421 longline vessels creating a number of 3709 fishermen in the field of longlining in Turkey (TÜIK, 2013), the production amount of the longline fishery hasn't been reported separately. This case is also considered to be a serious deficiency for Turkish longline fishery.

Longline fishing in Turkey is still being performed by traditional methods. Operational innovations such as boat, hook and bait type are needed in order to increase the longline fishery based production. This study aimed to present the potential use of alternative bait, Sepietta $s p$. and expose the preliminary results. Consequently Sepietta $s p$. was more efficient than $S$. pilchardus and $S$. vagina. The use of this species as a bait in longline fishery has also another importance from the perspective of evaluating a trawl discarded species. Many of the discarded species from trawl fishery or from other fishing methods are considered to have similar potential for reuse in longline and hand line fishery. Introduction of these discarded species such as Sepietta sp. as bait in longline and hand line fishing is also considered to have positive economic impacts on fishing industry especially for bait commerce. On the other hand such kind of an approach must be considered and managed very carefully against overexploitation for these discarded species. Further studies especially with commercial longline vessels about the bait type are required in order to develop this ecosystem friendly fishing gear in Turkey.

\section{ACKNOWLEDGEMENT}

This study was performed with the support of Ege University Scientific Research Project 2009/SÜF/025.

FAO (2005). Cephalopods of The World: An Annotated And Illustrated Catalogue Of Cephalopod Species Known To Date, Volume 1. Chambered nautiluses and sepioids. Rome, $649 \mathrm{pp}$.

Godøy, H., Furevik, D. \& Lokkeborg, S. (2003). Reduced by catch of red king crab (Paralithodes camtschaticus) in the gillnet fishery for cod (Gadus morhua) in northern Norway. Fisheries Research, 62: 337-384. doi: 10.1016/S0165-7836(02)00281-3

Hameed, M. S. \& Boopendranath, M. R. (2000). Modern Fishing Gear Technology, Daya publishing house, Delhi. $186 \mathrm{pp}$.

$\mathrm{He}, \mathrm{P}$. (1996). Bait loss from bottom-set longlines as determined by underwater observations and comparative fishing trials. Fisheries research, 27(1): 2936. doi: 10.1016/0165-7836(96)00477-8 
Jacobsen, J.H. \& Joensen, J. (2004). Comparison of bait in longline fishery. Bsc thesis. University of Faroe Islands, $54 \mathrm{pp}$.

Kınacıgil, H.T., Illkyaz, A.T., Metin, G., Ulaş, A., Soykan, O., Akyol, O. \& Gurbet R. (2008). "Balıkçılık Yönetimi Açısından Ege Denizi Demersal Balık Stoklarının İlk Üreme Boyları, Yaşları ve Büyüme Parametrelerinin Tespiti”, TÜBITAK, ÇAYDAG-103Y132 nolu Proje Kesin Raporu, $327 \mathrm{~s}$.

Løkkeborg, S. (1989). Longline bait: fish behaviour and the influence of attractant release rate and bait appearance. Dr. Sc. Thesis, University of Bergen, $109 \mathrm{pp}$.

Løkkeborg, S. (2000). Fish behaviour and gear improvement in longlining Fishing gear system 2000 Scottish Exhibition and Conference Centre Glasgow, Scotland.

Løkkeborg, S. \& Pina, T. (1997). Effects of setting time setting direction and soak time on longline catch rates. Fisheries Research, 32(1): 213-222. doi: 10.1016/S0165-7836(97)00070-2
Løkkeborg, S. \& Bjordal, A. (1992). Species and size selectivity in longline fishing: a review. Fisheries Research, 13(3): 311-322. doi: 10.1016/0165-7836(92)90084-7

Özdemir, S., Ayaz, A., Gurbet, R. \& Erdem, Y. (2006). Catch efficiency of bottom longline used with different hook size and different type bait at dawn and daytime (in Turkish with English abstract). Anadolu University Journal of Science and Technology, 7 (2): 405-411.

Sealifebase. (2016). Palomares, M.L.D. and Pauly, D., Editors. SeaLifeBase. World Wide Web electronic publication, <http://www.sealifebase.org/>.

Soykan, O. (2011). Seasonal distribution of by-catch species in Sığacık Bay by demersal trawl (in Turkish with English abstract), Ph.D. thesis, Ege University, Graduate School of Natural and Applied Sciences, 111p.

TUIK (Turkish Statistical Institute). (2013). Fishery statistics 2013, Ankara.

Ulaş A. \& Düzbastılar, F. O. (2001). Comparison of catch efficiency of different longlines (in Turkish with English abstract). Ege Journal of Fisheries and Aquatic Sciences, 18(1-2): 175-186. 